\title{
地籍情報関連の専門用語辞書構築
}

\section{The ontology construction of technical term for Cadastre}

\author{
藤井十章 \\ Kazuaki FUJII
}

\section{1 兵庫県土地家屋調查士会阪神支部位置参照点委員長}

Hyogo Cadasrtral Surveyors Association Hanshin lodge Reference Point System Management Group Leader 干650-0017 神戸市中央区楠町2丁目1番1号

\section{2 事務所}

Office

干665-0842 兵庫県宝塚市川面5丁目 10 番 2 号

E-mail: fzee@hera.eonet.ne.jp

あらゆる分野の専門家知識は、構造化がなされ、実用化に向かっている。近年、私たちはシマン テックウェブの技術の発展で、人工知能を身近に感じるとができる。たとえばスマートフォンの音声 検索機能のように。

地籍情報とは、国土管理する上での、土地財産情報 (境界の位置情報、面積及びそれに付随し た過程情報) と権利関係情報 (所有権または、占有及び抵当権利、規制など)である。日本の地籍は、 陸での国境がないなどで固有の土地管理により特化してきた。

世界測量者連盟(FIG)の土地管理のモデル化(LADM)の2012年11月 1 日ISO標準化から、地籍 の分野で専門家による日本の地籍情報のオントロジー工学による構造化により、特化された情報分 析が専門家の英知を通すことで、広く一般的な国土基盤情報となり、震災からの国土開発と日本の 財産管理を容易にするねらいことが求められている。専門家が人口知能を支える時代は来ている。

All of the knowledge of professionals will be oriented to the ontology. Recently we can see the artificial intelligence because of semantic web technology has advanced. For example, smart cell phone with intelligence knowledge voice navigator.

The cadastre are the information of properties (boundaries, Area, and its details of process) and the rights information (ownerships, occupations, mortgages, regulations, and rules) on land administration. Japan is island country. There for we don't have any borders on our land with other countries. Which made Japanese cadastre system very specialized.

The land administration domain model (LADM) by International federation of surveyors (FIG) was approved as an official international ISO Standard on 1 Nov 2012. And then, we need the spatial information to recover from the Tohoku Earthquake as fast as we can. The aim is making Japanese land administration easier. The time is coming to make the artificial intelligence knowledge by professionals.

キーワード：構造化，シマンテックウェブ，人工知能，地籍情報，国土基盤情報

Keywords : Oriented, Cadasre, FIG, LADM(Land Administration Domain Model), Spatial Data 


\section{1 専門用語辞書の必要性}

クラウドコンピューティング技術が一般化し、 Twitter, Facebookなどのソーシャルネットワーク サービスが世間一般に広がりを見せている。コ ンピュータデータ間の相関関係を分析・解析す るには、様々な方法があるが、データマイニン グなどの幾何学的な解析除き、多くの方法は、 言葉の引用数や意味することの互換性を定義 したものに基づいて、評価がなされることが一 般的である。

専門家の間で議論される用語定義される語 彙で、諸説ある解釈は、一般の人々は、どのよ うに理解して良いかは、容易なことではない。多 くの同一専門家による専門用語辞書 (オントロ ジー工学に基づいた、専門家の知識を構造化 したデータベースモデル)があれば、それがユ ビキタスサービスの上に提供されているもので あれば、そのような問題は、解消されるであろ う。

また専門家が提出する文書は、時に審査機 関の英知を超えるものが少なくない。そして、専 門家の用いる語句は、そのような場合は、審查 機関の知識レベルは、一般人の知識と同等で ある評価がなされる。このことは、行政手続き及 び最新のテクノロジーが一般化する速度を減速 させ、広く社会の利益とならない。

オントロジー工学を通じた、地籍辞書及び地 名辞書並びに測量テクノロジー辞書などを構築 することにより、専門家の存在意義と、経済活動 への有効利用が実現し、繰り返し行われる説明 や理解に要する時間が減ることに寄与できる。 誤った理解や用語の引用がなくなり、標準化さ れた専門用語の役割が果たされることになる。

以上は、夢見物語りではなく、現実に構築で きる技術論の上で述べていることであり、オント ロジー工学の技術者及びウェブサービスの管 理者、オントロジー工学の構築の基礎を理解し
た、専門家チームにより実現できる。

\section{2 専門家辞書とは}

\section{1 辞書とは}

専門家の辞書とは、どのようなものであるか、ま ず触れておきたい、いわゆる「辞書」と聞くと一 般的な、分厚い本を想像するに違いない。構造 的にまとめたということでは、そうかもしれないが、 人工知能としてのデジタルデータであることが そもそも必要な要件である。

\section{2 専門家辞書とは直接誰が使うのか}

直接誰が使う辞書であるか。その答えは、コ ンピュータである。オントロジー工学でいう辞書 とは、コンピュータがデータを読み込む際に、文 字データなのか数值データなのか、日付なのか、 バイナリデータであるのか、様々なデータの種 類を理解させることが必要であると同時に、その データの意味を付加することが重要である。

たとえば「12.345」という数字は、距離なのか 標高なのか、何なのかコンピュータは理解でき ない。また、土地の面積で土地の利用目的(地 目)が山林である場合は、「12」となり、小数点以 下を切り捨てて表示することになっている。そう いった詳細は、専門家でこそ理解できるが一般 の人では知り得ない細かな法律もある。

いわゆる辞書といらのは、コンピュータが現実 世界の事柄 (オブジェクト)を理解し、適正なス キームで情報を処理して表示するという作業過 程で使用するデータ構造体でその他いろいろ な方法がるが、私が考えるオントロジーサービス は、記述方法もWWWに規定されたOWLという 言語により可能となる。

専門家の辞書(オントロジーサービス)を通せ ば、そのようなデータを受け取った際は、どのよ うな数值的な処理を行えばよいかといらことを判 
断し、また、その処理は、どの法律に寄り定めら れているのかといらこともその数值データから検 索が可能となる。

\section{3 どのように構築するのか}

\section{このセッションでいら構築は、技術的なことは} あえて述べない。オントロジーを構筑する上で、 専門家が取る構築での役割を中心として述べ て行きたい。

\section{1 オントロジ一構築の仕組みを知る}

オントロジー構築には、いろいろな方法があ るが、代表されているソフトウェアにOWL, 法造 などがある。構築に際してソフトウェアと、対象 の概念があり、その操作が理解できれば、誰で もオントロジーが構築できる。したがって、オント ロジー構築は、知識がベースになっているため、 構築する分野での精通した知識がなければ、 構築しえない。その過程において、オントロジー の技術者は、オントロジーがどのように構築され ているのか理解できる為、専門家が構築した概 念の説明を受けたときに、適正に構築している か否かという判断の添削できるし、情報の機密 性を確保することができる。

大阪大学溝口理一郎教授がオントロジーとは 「対象世界をどのように見ているかという根源的 な問題意識を持って物事をその成り立ちから解 き明かし、それをコンピュータと人間が理解を共 有できるように書き記したもの」[1]と定義してい ることからも、専門分野での問題意識、その成り 立ちに精通し、構築過程までの品質管理がで きなければ、真に言う地籍のオントロジーには ならないことを意味する。

\section{2 オントロジ一構築組織化と実態業務 の流れ}

実際の構築に際して、組織化された専門的 なチームは、ネットワーク社会におけるコミュニ ケーション能力に長けていることが条件となる。 社会制度の基盤となる情報は、言わずもがな全 国に情報が広がり、日々変化していき、初期段 階では、大量の情報を構築していかなければ ならい。また、専門家の知識自体が構造化の側 面を考慮して、把握されていないことが想定さ れるため、その工程の確認や、マネージメントが 複雑化しや寸い側面を持つ。

実際は、物作りの工程に近いものがある為、 向上の生産管理マネージメント技術が応用でき る。配慮すべきところは、高度な情報を持つ専 門家は、高齢化しているということに尽きる。ヒア リングの精度の高さは、現実的に難しい課題と なるだろう。

\section{4 地籍オントロジーの必要性}

\section{1 専門家辞書と活用}

前の章で、専門家辞書とは何かと構築につ いて述べた。専門知識のオントロジーはインタ 一ネット上に web サービスとして提供される。 地籍に関するあらゆるソフトウェアは、その才 ントロジーのサービスをベースとしたアプリケ ーションを構築できる。従来の開発過程とは、 ソフトウェア制作会社が独自のユーザーとのヒ アリングにより、そのニーズと、アプリケーション の利用による業務効率化を歌い販売し、その 利潤を得るといらサイクルを持っており、その 開発コストもそれぞれの会社の開発コストとな っていた。

専門家のオントロジーを構築することにより、 今まで情報として得られなかったユーザーか らのヒヤリングや、専門知識の構築にかかる、 特化した理論の内容までが構造化されること 
により、業界内での共通認識を踏まえた上で の、開発が可能となる。

他方で、国民は、専門家の構築した知識基 盤を元に、用語の検索や、解説、法律の検索 が可能となり、Wikipedia のような、不特定多 数のユーザーによる書き込みと、その監視体 制による、システムの不安材料を克服すること ができる。あくまで、前述による専門家団体の 運営による、オントロジーの運営が前提である ことは、言うまでもない。

他方で、昨年の11月 1 日に FIG（世界測量 者連盟)による、土地管理領域モデル(

LADM) が ISO の標準となり、土地情報とそ の権利関係が XML 構造化された。こういった 国際的な情報構造化の波も押し寄せている。

この章では、構築を述べたオントロジーを利 用して、地籍に関してのオントロジーが広く一 般にどのような効果をもたらすのかについて、 具体的な例をあげて述べて行きたい。

\section{2 専門家の未熟性への支援}

新しく開業した資格者は、ベテランの資格 者の知識と比べるとその差があることは明確で す。専門家の知識を得ることの研鑽は法律に も規定されていることであるが、その過程にお いても、業務を行う。足りない知識の補充基盤 となり側面は、オントロジー構築を行うべテラン の専門家からの知識の伝授を意味している。

\section{3 誤つた知識の是正}

誤った知識による事故防止が重要な要素で ある。社会人となった人間は、年を経るにつれ、 誤ったことを指摘さにくくなる傾向にあることは、 専門家知識でなくてもあり得ることである。専 門家であるゆえに、知っていて当然といら社会 通念や資格者としての存在意義自体も、そう いったことを冗長する。知識の集合から、自ら
指摘された部分を知るきっかけとなることが期 待できる。

\section{4 複数ある法律見解の集約化}

オントロジーは、すべての知識を表現してい なければならい。法律では、いろいろな解釈 が存在するのであって、すべての考え方を網 羅し、仮に内容に含まれていないオブジェクト があれば、追加すれば足りる。 法解釈が一般化していることが前提となるの であろうが、その線引きは難しい。

\section{5 地域慣習による取扱}

4.4 に述べたことがらに共通するが、日本全国 にある風習や、行政による事務取扱も様々な ものがあり、風習に関しては、テレビ番組にも なるぐらい、各地域の当たり前といらものが、多 岐にわたることは、地籍の分野にも例外は無 い。

\section{5 最新のテクノロジーの運用}

最新の研究が日夜行われ、測量の分野にお いても、3Dスキャニング、人工衛星を使った 測量、ラジコン飛行機・ヘリコプターを使った 測量など、今までの測量手法ではない技術が 開発される。測量の結果の表示方法は法律で 規定されているものの、一部の作業を除き、測 量する方法は限定されていることはない。審査 機関の研修は、それらをカバーするくらい頻 繁に行われているものではない為、そうした最 新の技術を使用することになった場合、どうし ても説明するときの知識が足らない可能性が ある。国内において、同じ審査が行われる時 に、その知識の標準化がされたものがあれば、 専門家は、その業務の重要な論点整理に集 中することができるため、作成する側も審査す る側、簡素化されることになる。 


\section{7 過去の取り扱いやその知識について} 明治期からの地租改正による土地情報の 取り扱いや、その以前による土地情報の知識 は、広く一般に公開されていることは少ない。 土地の情報は、地域特有の問題点も含んで いることが少なくない。

作業者としての配慮するべき内容も、専門 家内で個別に情報交換されることもない。審 查を受ける際の報告書にも、そういった調査 内容が含まれることが多いため、調査する前 の段階で、それを熟知している必要性がある。

こういった、伝承しにくい情報がより、一般 的になることが専門家としての役割が大きい部 分であるとは、認識して頂けるだろう。

\section{8 震災からの復興}

東北でも大地震が起きました、これらを復旧 することに関して、現場での作業が急がれて います。2年が経ち、進捗は思うように進みま せん。

専門的な知識は、県外からの救援を行う際 に、県内のベテランの知識との格差を埋めるこ とになります。住んでいる地域のことは、理解 していると自負される専門家が多いですが、 大惨事に見舞われた場合に、その他の地域 から作業に来られた専門家との協力関係を気 付いて、「減災」と「早期復興」を考えてもよい のではないでしょうか。

\section{5 問題点}

\section{1 熟練専門家の知識の伝達}

地籍オントロジーを構築する上で、問題とな るのが、熟練した専門家がその知識を提供し にくい問題である。これは2つの側面があり、1 つは、知識を保有していることが、その資格者
個人の利益や同業との差別化するツールにな っていると考えているからで、これからの社会 的な利益への理解が、実感できる専門家が少 ない。また2つ目に、近年のコンピュータ情報 技術(パソコン)の知識を持たない熟練者が多 い。

\section{2 情報処理に関しての知識の保持}

日本における測量士及び土地家屋調査士 が測量作業においての専門資格に位置づけ れているが、その資格取得の過程で、情報処 理技術を学ぶ過程は一切ない。

アメリカにおいて、測量に関しての技術者と なるものは、測地学の要素以外にも、コンピュ ータプログラミングや、地図上に情報を載せる 地理情報システム (GIS)などの知識を身につ けなければならない。

資格取得過程において、そういった試験内 容の改訂など、各制度自体の欠陥が地籍とい う基盤を構築する弊害となっている。

\section{6 まとめ}

国際的な地籍分野における情報構造化の波 は、必ず日本に影響を及ぼし、各国の専門家 の知識は、共有化される方向へ進む。それは、 土地の管理情報の共通化をはかり、より国境を 越えた取引を円滑にするといら目的がある。地 域慣習などは、国を超えると宗教問題、食糧問 題を加え、さらに問題が複雑になることが多い が、各国の努力に期待する面もある。

専門家の知識は、長年培ってきた努力と、そ の英知のリサイクルを実現しなければ、社会的 な「知」とはならない。地籍を通した専門家の知 識は過去から未来へと広がり、その情報も増え て行くことは間違えない。掲げられた問題は、 行政と関連団体の研鑽により実現できるものと 
信じるし、より早期に専門家の知識をオントロジ 一として社会に役立てる活動は、日本社会全 体の発展に不可欠なものであり、発展の速度の 早めるまた、経済を強固なものにする基盤にな る。

\section{参考文献}

[1] 溝口理一郎：「オントロジー工学」,
オーム社, 1章 pp. 3, 2005.

[2] 溝口理一郎：「オントロジー構築入門」, オーム社，1章 pp. 1， 2005.

［3］赤間世紀；「オントロジーがわかる本」, 工学者, 1.3 pp. 16- 24, 2010.

[4]記述論理とWebオントロジー言語 オーム社 1.1.1 2 - 62009 